\title{
Genetic diversity, population structure and taxonomy of Calopteryx splendens (Odonata: Calopterygidae): An AFLP analysis
}

\author{
SABER SADEGHI ${ }^{1,2}$, TINA KYNDT ${ }^{3}$ and HENRI J. DUMONT ${ }^{1 *}$ \\ ${ }^{1}$ Department of Biology, Gent University, Ledeganckstraat 35, B-9000 Gent, Belgium \\ ${ }^{2}$ Department of Biology, Shiraz University, Shiraz, Iran; e-mail: sabersadeghi@yahoo.com \\ ${ }^{3}$ Department of Molecular Biotechnology, Gent University, Coupure links 653, B-9000 Gent, Belgium; e-mail: tina.kyndt@ugent.be
}

Key words. Odonata, Calopteryx, AFLP, genetic structure, diversity, gene flow

\begin{abstract}
Calopteryx splendens is a widely distributed palaearctic damselfly with a remarkably uniform morphology. Variation in the size and shape of the pigmented spot on the wing is the main diagnostic character used to discriminate subspecies across its huge geographic range. Here, AFLP analysis was used to assess the genetic structure and diversity of nine populations representing 3 putative subspecies and evaluate the pigment spot as a taxonomic marker. Genetic diversity was high, with the number of polymorphic loci per population ranging from 141 to 280 out of a total of 333 variable sites $(42.3-84.1 \%)$ and Nei's gene diversity from 0.160 to 0.283 (overall 0.299 ). Overall population genetic differentiation $\left(F_{S T}=0.2766\right)$ suggests limited gene flow and adaptation to local environments. Restricted gene flow and genetic differentiation among populations are supported by significant $F_{S T}$ estimates. High levels of gene flow $\left(N_{m}>1\right)$ were only recorded among three Asian populations (Russia - Kazakhstan - Turkey). The patterns of genotypic diversity suggest that a given wing spot size and shape may arise from the hybridization of a limited number, possibly not more than four, ancestral gene pools in different ways and at different times. Clearly, the sample analyzed was not sufficient to capture all of the complex history of $C$. splendens, but sufficient to indicate the taxa ancilla, waterstoni, and orientalis possibly represent three of the four ancestral gene pools, and originated in western Asia. The origin of the fourth, xanthostoma, is the western Mediterranean.
\end{abstract}

\section{INTRODUCTION}

Calopteryx (Odonata: Calopterygidae) is a genus of large and colourful damselflies with bright metallic bodies. Its members are restricted to running water and migrate over short distances, i.e. they are, on average, poor dispersers (Dumont, 1975; Stettmer, 1996). The wings of males of Calopteryx splendens Harris have iridescent blue veins, usually partly covered by a spot that is a secondary sexual character, which plays an important role in the courtship display (Askew, 2004). Males court females by flashing their spotted wings during their courtship flight (Askew, 2004; Corbet, 2004).

Studies on a Calopteryx of the splendens-group $(C$. xanthostoma) have shown that the extent of wing pigmentation is heritable but also correlates to some degree with the fat reserves and number of parasites hosted (SivaJothy, 2000; Cordoba-Aguilar et al., 2002; Koskimaki et al., 2004). Hopeman \& Abramson (2005) found no correlation between degree of wing pigmentation and male mating or territorial success in C. maculata, but most results suggest that wing pigmentation is a signal of male quality (Grether, 1996; Tynkkynen et al., 2004; Hopeman \& Abramson, 2005). Waage (1975) and Grether (1996) found that visual discrimination based on wing pigmentation is a major component of behaviour-based reproductive isolation between species.
In Europe, there are three well-defined, reproductively (almost) fully isolated species (C. virgo, C. splendens, and $C$. haemorrhoidalis) that can be identified by wing shape and colour, and colour of the ventrum of the male terminalia. No structural differences in the sexual organs exist. Of these, C. splendens is taxonomically the most complex. It also occupies the widest range, extending from North Africa to Europe and West-Central Asia as far north as $60^{\circ} \mathrm{N}$, bounded in the East by the south end of Lake Baikal and the extreme south-west of Mongolia and of Xinjiang. More than a dozen "subspecies" and subspecific ranges have been catalogued in the last hundred and fifty years (Dumont, 1972). None of these can be separated structurally; they are identifiable only by the extent of the wing spot in males and by geographic range (Dumont et al., 1987, 1992, 1997, 2005), but whether the wing spot alone is sufficient for the delimitation of subspecies is uncertain. Studies on ethological and especially genetic differences for characterizing such infra-specific categories are necessary. Yet, to our knowledge, only two formal population genetic studies of $C$. splendens have to date been done, one in Sweden and one in France (Svensson et al., 2004; Chaput-Bardy et al., 2008) and both at a geographic scale too local to be of taxonomic significance.

Wing spots in males vary between absence (e.g. in ssp. waterstoni and hyalina) and almost complete coverage of the wings (only the wing base hyaline, e.g. in ssp.

\footnotetext{
* Corresponding author; e-mail: henri.dumont@ugent.be
} 
ancilla), with sometimes the tip of the wing slightly hyaline and females either with (androchrome) or without (gynochrome) a wing spot. Two further forms are xanthostoma (wing spot from near nodus to tip of wing), found only in the West Mediterranean although similar phenotypes occur in the Balkans and Western Asia, and orientalis (wing spot commencing halfway between nodus and wing tip and extending to wing tip). The form ancilla, also known under a variety of younger names (intermedia, balcanica, caprai, faivrei), is the most widely distributed phenotype. It occurs in the south of France, Italy, most of the Balkans south of Croatia, Poland, the Baltic States, extends into Russia and much of the $\mathrm{Ob}$ catchment, including the Irtysh subbasin, and is present in Anatolia, much of Iran, Afghanistan and parts of Uzbekistan. In contrast, orientalis is limited to the southern fringe of the Caspian Sea, and the related syriaca lives only in some Levantine valleys like those of the Jordan and Litani Rivers. Pure waterstoni is only found in a restricted coastal fringe along the south-eastern Black Sea. Forms with a reduced wing spot are named taurica, tchaldyrica, mingrelica, and cartvelica. They grade into $C$. splendens splendens, where the wing spot is centrally situated and there is a broad hyaline wing tip.

All adjacent wing-spot types hybridize and are easily identified where clines in wing spot extent occur. Hybrid populations can be spotted in the field if they are intermediate between the parental taxa, but experimental hybridization has shown that this is not always the case (Lindeboom, 1998): some hybrids look like one of the parent subspecies, and thus, molecular discrimination is necessary as wing spot analysis captures only part of the underlying genetic variation.

The goals of the present study were to: (1) characterize the genetic diversity, structure and population differentiation of Calopteryx splendens across a broad geographic area of Eurasia; (2) assess the geographic distribution of genetic diversity within and between $C$. splendens populations; (3) compare the prevalence of intraspecific gene flow with morphological differentiation.

To do this, specimens from nine populations across Eurasia were genotyped using the amplified fragment length polymorphism (AFLP) technique, developed by Vos et al. (1995). This technique continues to be widely used in analyses of genetic variation below species level, particularly in investigations of population structure and differentiation (Mueller \& Wolfenbarger, 1999; Bensch \& Åkesson, 2005; Lowe et al., 2003 ).

\section{MATERIALS AND METHODS}

\section{Animal material}

This study was performed on Calopteryx splendens (Har.) s.l. from Eurasia. Specimens were collected by the authors and their colleagues. Table 1 summarizes the characteristics of the populations sampled, including their geographical location and coordinates (Fig. 1). Each specimen was preserved initially in $70 \%$ ethyl alcohol, cleaned and then preserved separately in fresh $70 \%$ ethyl alcohol after examining them in the laboratory. In total, 114 male specimens from nine populations were used in the analysis.

\section{Genomic DNA extraction}

DNA was extracted from thoracic muscle using the protocol of the Puregene DNA Isolation Kit type D-5000A (Gentra Systems, Inc., BIOzym, Landgraaf, The Netherlands).

\section{AFLP procedure}

Five hundred nanograms of genomic DNA per individual were digested simultaneously with $0.5 \mu \mathrm{l}(5 \mathrm{unit} / \mu \mathrm{l})$ of EcoRI (Invitrogen, Carlsbad, CA, USA) and MseI (New England Biolabs, Ipswich, MA, USA) at $37^{\circ} \mathrm{C}$ for $1 \mathrm{~h}$. Following digestion, EcoRI and MseI adapters were ligated to restricted fragments at $37^{\circ} \mathrm{C}$ for $3 \mathrm{~h}$. A 1: 4 dilution of the restricted and adapter-ligated DNA was used as a template in the pre-amplification reactions. Pre-amplification products were generated using an EcoRIprimer with one selective nucleotide $(E c o R I+T)$ and MseIprimer with another selective nucleotide $(M s e \mathrm{I}+\mathrm{C})$.

Pre-amplification was performed by a thermocycler (TechneProgene, Rockville, MD, USA) using pre-heating, $94^{\circ} \mathrm{C}$ for 2 min and then 20 cycles: $94^{\circ} \mathrm{C}$ for $30 \mathrm{~s}, 56^{\circ} \mathrm{C}$ for $30 \mathrm{~s}, 72^{\circ} \mathrm{C}$ for $60 \mathrm{~s}$ and finally post-heating, $72^{\circ} \mathrm{C}$ for $10 \mathrm{~min}$. After estimating the concentration of the PCR product using $1 \%$ agarose gel electrophoresis, a second round of selective amplification was performed. At this stage, a $1: 10$ or $1: 5$ diluted pre-amplified DNA (related to the PCR product concentration at preamplification) was amplified using two fluorescently labelled EcoRI primers carrying three selective nucleotides (FAM-EcoRI primer + TAG, NED-EcoRI primer + TGA) in combination with $M s e I$ primers including three selective nucleotides (MseI primer + CAC, MseI primer + CCG). Our choice of pre-selective and selective primer pairs was based on the study of Svensson et al. (2004) and results of a pilot study using seven different primer combinations.

TABLE 1. Number of specimens, where and by whom they were collected.

\begin{tabular}{lrll}
\hline $\begin{array}{l}\text { Population } \\
\text { (Country) }\end{array}$ & No. & Locality & Collector \\
\hline Azerbaijan & 13 & Kura valley, Agsu, 8.ix.2004, (40:34 N, 48:23 E) & H.J. Dumont \\
France & 12 & Canal au bord du Rhone, Gard, 12.vii.2004 & H.J. Dumont \& M. Papazian \\
Finland & 13 & Espoo, S Finland, 25.vi.2004 (60:12 N, 24:39 E) & M. Hamalainen \\
Iran & 12 & Cheshmeh Belgheis, Dehdasht, 14.viii.2003 (30:43 N, 50:31 E) & S. Sadeghi \& A. Johargholizadeh \\
Kazakhstan & 8 & Irtysh River, China Border, 11.vii.2004, & H.J. Dumont \& A. Haritonov \\
Russia & 17 & South Ural, 18.vii.2004 (52:41 N, 58:54 E) & H.J. Dumont \& Haritonov \\
Slovenia & 19 & Rakov Skocjan, near Rakek, 2005 (45:47 N, 14:17 E) & H.J. Dumont \& A. Brancelj \\
Spain & 3 & Ponte Caldelas, Vendugo River, 13.vii.1999 (42:23 N, 8:29W) & A. Cordero \\
Turkey & 17 & Hakkari, W Yuksekova, 24.vi.1998 (37:34 N, 43:45 E) & H.J. Dumont \\
\hline
\end{tabular}




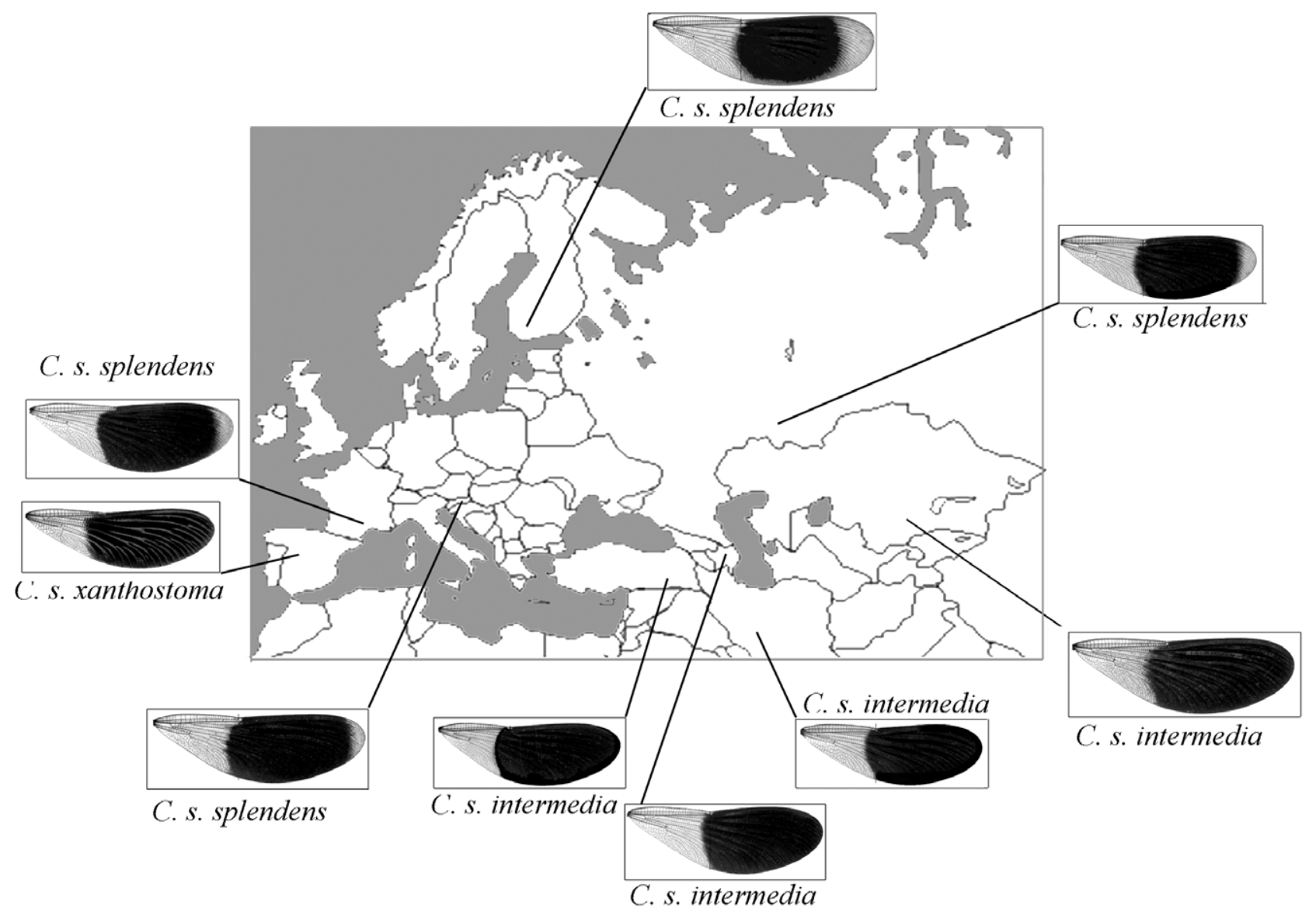

Fig. 1. The localities of the populations studied and photographs of the general form of the left fore wing of an individual from each the populations.

\section{Capillary electrophoresis}

Following amplification, samples were loaded onto the 16capillary system of the Applied Biosystems $3130 x l$ Genetic Analyzer (Applied Biosystems, Foster City, CA, USA), in a 10 $\mu 1$ volume containing $0.5 \mu \mathrm{l}$ of the selective amplification product mixed with $0.8 \mu \mathrm{l}$ of the gene scan $600 \mathrm{LIZ}$ size standard (Applied Biosystems P/N 4366589) and $8.7 \mu 1$ of Hi-Di formamide (Applied Biosystems P/N 4311320). A $50 \mathrm{~cm}$ capillary array (Applied Biosystem $\mathrm{P} / \mathrm{N} 4315930$ ) and 3130 pop-7 polymer (Applied Biosystem $\mathrm{P} / \mathrm{N}$ 4363785) were used. In total, the four primer pairs generated 333 polymorphic loci (AFLP markers), which were used in the analysis.

\section{Data analysis}

The AFLP markers were scored as present/absent in each individual by the GeneMapper software of the 3130 Genetic Analyzer. The resulting binary data matrix was analyzed using the NTSYS-pc software package (Version 2.11; Rohlf, 2004) to determine similarities among pairs of individuals. Genetic similarities based on Jaccard's coefficient (Jaccard, 1908) were calculated using the SIMQUAL module of NTSYS-pc. From this similarity matrix an Unweighted Pair Group Method (UPGMA; Sokal \& Michener, 1958) dendrogram was generated using NTSYS-pc. Principal co-ordinate analysis (PCoA) was performed to represent inter-individual and inter-group relationships using the DCENTER and EIGEN modules of NTSYS-pc. A three dimensional plot was produced to illustrate the genetic similarities between individuals.

Genetic diversity and population genetic structure were evaluated using the program AFLP-SURV (Version 1.0; Vekemans,
2002), which computes the genetic distance between populations based on two approaches: that of Lynch \& Milligan (1994) or Nei's gene diversity, and that of Clark \& Lanigan (1993) for RAPD loci, extended for AFLP by Innan et al. (1999). Allelic frequencies were computed from the observed frequencies of fragments using the Bayesian method with non-uniform prior distribution of allele frequencies (Zhivotovsky, 1999) for diploid species, assuming Hardy-Weinberg genotypic proportions. Nei's (1973) gene diversity (also known as expected heterozygosity), global and pairwise genetic differentiation $\left(F_{S T}\right)$ values were computed. Significance of the genetic differentiation between groups was tested by comparison of the observed $F_{S T}$ with a distribution of values assuming no genetic structure, obtained by means of 1000 random permutations of individuals among populations.

Analysis of molecular variance (AMOVA; Excoffier et al., 2005) in ARLEQUIN (Version 3.1, 2005; Schneider et al., 1996) was performed to test the distribution of genetic variability among and within populations. This approach involves a hierarchical partitioning of the observed genetic variation, evaluated at three levels: differences between groups, differences among populations within groups and differences within populations (genetic variation attributable to individuals). A non-parametric procedure with 1023 permutations was used to test the significance of variance components associated with the different levels of genetic structure. The average level of gene flow $\left(N_{m}\right)$ among populations was calculated based on the $F_{S T}$ value (Slatkin, 1989, 1991) according to the equation

$$
N_{m}=\frac{1}{4}\left(\frac{1}{F_{S T}}-1\right)
$$


TABLE 2. Number of polymorphic markers, polymorphism rate (\%), and gene diversity within the 9 populations of C. splendens analyzed, based on 333 AFLP markers.

\begin{tabular}{lcccc}
\hline Population & Polymorphic loci & \% polymorphic loci & Nei’s Gene diversity & SE (Standard Error) \\
\hline 1 - Azerbaijan & 280 & 84.1 & 0.283 & 0.0096 \\
2- France & 278 & 83.5 & 0.267 & 0.0090 \\
3 - Finland & 141 & 42.3 & 0.172 & 0.0098 \\
4 - Iran & 178 & 53.5 & 0.208 & 0.0108 \\
5 - Kazakhstan & 178 & 53.5 & 0.161 & 0.0096 \\
6- Russia & 198 & 59.5 & 0.217 & 0.0103 \\
7 - Slovenia & 147 & 44.1 & 0.160 & 0.0102 \\
8- Spain & 199 & 59.8 & 0.235 & 0.0099 \\
9- Turkey & 225 & 67.6 & 0.246 & 0.0100 \\
\hline
\end{tabular}

using ARLEQUIN, where $N_{m}$ is the absolute number of migrants exchanged between two populations.

\section{Structure}

To infer genetic structure within the range of population samples and define genetic relationships between populations with many morphological similarities, genetically homogenous populations ("gene pools") were identified by an ad hoc designed clustering approach implemented in the software STRUCTURE (Version 2.2, 2007, http://pritch.bsd.uchicago.edu/structure. html). The program uses a Markov Chain Monte Carlo (MCMC) algorithm to cluster individuals into gene pools on the basis of multilocus genotype data (Pritchard et al., 2000; Falush et al., 2003); it has also been applied to problems such as identifying cryptic population structure (Pritchard et al., 1999), detecting migrants or admixed individuals and inferring historical population admixture (e.g. Rosenberg et al., 2002; Falush et al., 2003, 2007; Albert et al., 2006). STRUCTURE assumes that all the genetic material of the individuals sampled comes from one or more of $K$ unobserved populations or gene pools (Falush et al., 2007). The software places specimens in $K$ clusters that have distinct marker frequencies, where $K$ is chosen in advance and can be varied across different runs. This method, therefore, attempts to assign individuals to gene pools on the basis of their genotypes, while simultaneously estimating population allele frequencies.

On the presence/absence matrix an admixture ancestry model was used and allele frequencies were correlated with a burn-in period of 100,000 generations and MCMC simulations of 100,000 iterations. Then "STRUCTURE" was run ten times for each $K$ value, where $K$ is the potential number of gene pools in the overall sample of individuals. The most likely number of gene pools was determined by $\Delta(K)$ as described in Evanno et al. (2005). Then individuals of the nine populations were assigned probabilistically to the inferred gene pools. The outputs of STRUCTURE (individuals and population Q matrices) were displayed using Distruct software, Version 1.1, 2007 (Rosenberg, 2004)

\section{Mantel test}

The Mantel test (Mantel, 1967), a permutation test for estimating the correlation between two distances or similarity matrices (see Mantel, 1967; Sokal \& Rohlf, 1995; Sokal, \& Wartenberg, 1983), was used to evaluate the relationship between geographic distance and genetic differentiation of population pairs. The shortest geographic distances between populations were calculated using an online distance calculator (http://www.infoplease.com/atlas/calculate-distance.html). Geographic distances were then compared with $F_{S T}$ values between populations using the MXCOMP module of NTSYS-pc (Rohlf, 2005).

\section{RESULTS}

\section{AFLP marker profile}

A total of 333 AFLP markers ranging in size from 50 to $400 \mathrm{bp}$ were generated using four primer combinations. The presence/absence of these markers was assessed across the entire collection (114 demoiselles, 9 localities). The number of scored individuals, number and percentage of polymorphic loci and their genetic diversity, calculated using AFLPsurv, are summarized in Table 2.

The Azeiri population with 280 variable loci $(84.1 \%)$ and Finnish population with 141 variable loci $(42.3 \%)$ were the most and least variable populations, respectively. Nei's gene diversity (or expected heterozygosity within the population) ranged between 0.160 (Slovenia) and 0.283 (Azerbaijan).

\section{Principal co-ordinate analysis}

PCoA partitioned the genetic variance among the principal co-ordinates of the complete data set. The first three principal co-ordinates (Fig. 2) explain 23.4\%, 9\%, and $7.6 \%$ of the total variance ( $40.02 \%$ cumulative).

The plot shows three distinct clusters. The first two coordinates separate two groups at the two ends of the field and one mixed group in between. The group largely includes individuals from the Azeiri and French populations, which are separated by the third co-ordinate. On the right hand side a group consisting of Finnish and Slovenian individuals is formed. Turkish, Russian, Spanish, and Iranian populations form the middle cluster. The third axis separates the main populations within these groups. There is limited mixture of Turkish and Azeiri populations, and Iranian and Slovenian individuals. Unexpectedly, the Spanish individuals are not well separated in this plot, possibly due to the small sample size $(\mathrm{N}=3)$.

\section{Structure}

The model-based clustering method of Pritchard et al. (2000) using an admixture model with correlated allele frequencies was applied to the data set without using prior information on the number of populations. This STRUCTURE analysis identified 7 distinct clusters (Fig. 3).

The most obvious pattern is the close genetic relationship of the Kazakhstan and Russian samples on the one hand, and the Finnish and Slovenian populations on the 


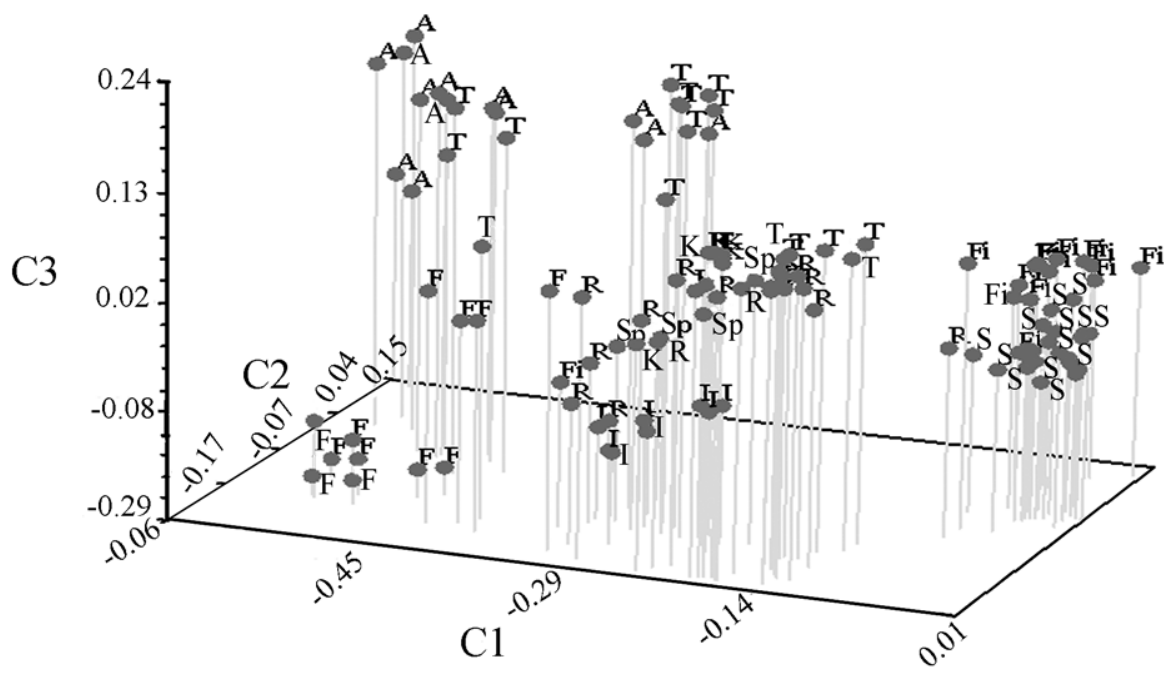

Fig. 2. Principal co-ordinate plot based on genetic similarity between 114 individuals from nine populations (1-9), A Azerbaijan, F - France, Fi - Finland, I - Iran, K - Kazakhstan, R - Russia, S - Slovenia, Sp - Spain, T - Turkey.

other hand, although both contained traces of the other's gene pools. Azerbaijan, France, and Spain showed independent gene pools with some admixture from the Russia-Kazakhstan gene pool and a very slight admixture from other gene pools. The Iranian population too had a largely independent gene pool, including some admixture from Finland-Slovenia, and the Spanish population had an independent gene pool with traces of the RussianKazakh gene pool. The Turkish population contained elements from the Azerbaijani and Russian-Kazakhstani gene pools. The 7 th gene pool was present as a trace in some populations. Azerbaijan and France were close to each other in the cluster analysis (see below) but in the $K$ $=7$ analysis, they had separate gene pools.

The assessment of the distribution of genetic variability among and within the 9 geographically distant populations, estimated by the Lynch and Milligan method using AFLP-SURV 1.0., gave a total gene diversity $\left(H_{t}\right)$ of 0.2993 , with the mean gene diversity within $\left(H_{w}\right.$, analogous to Nei's $H_{s}$ ) populations 0.2165 (SE 0.015) and among ( $H b$, analogous to Nei's $D_{s t}$ ) populations 0.0827 (SE $0.009)$. Wright's fixation index $\left(F_{S T}\right)$ (Wright, 1951) was 0.2766 (SE 0.091). The observed value of $F_{S T}$ was significantly genetically differentiated from random assemblages of individuals $(P<0.0001)$. Pairwise $F_{S T}$ values

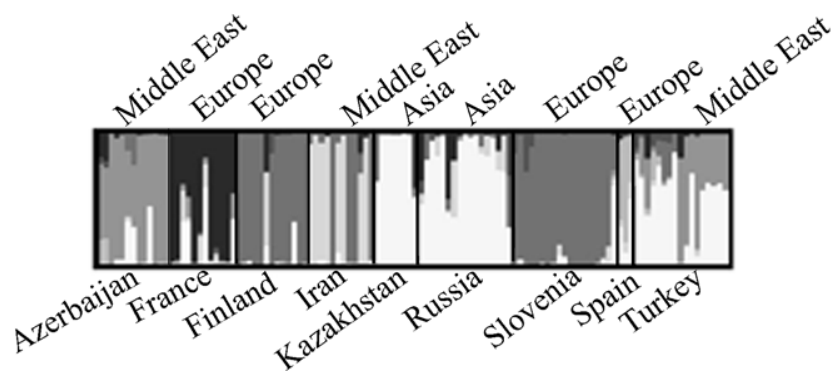

Fig. 3. Estimated population structure for all individuals. Each individual is represented by a vertical line of a different shade of grey, partitioned into $\mathrm{K}$ segments that represent the individual's estimated membership of $K=7$ gene pools. were calculated between all populations, and a UPGMA tree was computed from the matrix of distances (Fig. 3). The collections from Russia and Kazakhstan were much more similar to each other than to those from Slovenia and France.

\section{Cluster analysis within and among populations}

To test the findings from the $F_{S T}$ statistic an Analysis of Molecular Variance (AMOVA) was carried out using Arlequin version 2.001 (Schneider et al., 2000). On the basis of the haplotype scores, the genetic differentiation $\left(\varphi_{\text {st }}\right)$ between all pairs of taxa was estimated using a phenetic method (Table 5, model 1). About $60.8 \%$ of total genetic variability among samples could be attributed to genetic differentiation within the nine populations, the remaining 39.2\% was due to genetic differences between populations $\left(\varphi_{\mathrm{st}}=39.2 \%\right)$. Pairwise comparisons of $\varphi_{\mathrm{st}}$ values (Table 3 ) among populations confirmed the presence of significant genetic differentiation between all the populations analyzed.

The Mantel test revealed no significant correlation $(P>$ $0.05)$ between genetic differentiation $\left(\varphi_{\text {st }}\right)$ and geographical distance matrices based on 100,000 random permutations. The lack of correlation between the geographic distance between populations and genetic (dis)similarity implies that factors other than isolation-bydistance are involved in the genetic isolation of the populations.

In the UPGMA dendrogram based on AMOVA-derived pairwise $\varphi_{\text {st }}$ distances (Fig. 4), four clusters can be identified. Group I combines the populations from Azerbaijan and France, although at relatively large distances. Group II includes four Asian populations: Iran, Kazakhstan, Russia and Turkey. The Spanish population appears in a separate branch as group (III), while group IV clusters the Finnish and Slovenian populations. In the UPGMA dendrogram, the group IV and the Spanish population are most divergent from the other populations. The Russian and Kazakh populations are the most genetically similar, as expected from their geographical relationship. This 
TABLE 3. Pairwise geographic distance (above the diagonal) and genetic differentiations ( $\varphi_{\mathrm{st}}$ values) (below the diagonal) from the AMOVA. All $\varphi_{\text {st }}$ values are significant $(P<0.01)$ after 1000 permutation; maximum and minimum values are in bold type.

\begin{tabular}{lccccccccc}
\hline Populations & Azerbaijan & Iran & Turkey & Kazakhstan & Russia & Spain & Slovenia & Finland & France \\
\hline Azerbaijan & - & 1138 & $\mathbf{4 8 7}$ & 2949 & 1864 & 4675 & 2809 & 2729 & 3591 \\
Iran & 0.42890 & - & 1022 & 3365 & 2868 & 5434 & 3629 & 3846 & 4353 \\
Turkey & 0.26128 & 0.29116 & - & 3424 & 2347 & 4477 & 2639 & 2875 & 3390 \\
Kazakhstan & 0.48886 & 0.40605 & 0.22097 & - & 1910 & 6870 & 5153 & 3980 & 5108 \\
Russia & 0.42523 & 0.26089 & 0.18491 & 0.07675 & - & 4967 & 3309 & 2127 & 4048 \\
Spain & 0.42729 & 0.40532 & 0.32252 & 0.54739 & 0.37926 & - & 1668 & 2994 & 1088 \\
Slovenia & 0.57441 & 0.28285 & 0.38606 & 0.47088 & 0.36520 & 0.53782 & - & 1742 & 796 \\
Finland & 0.53434 & 0.38174 & 0.36787 & 0.49105 & 0.38853 & 0.55128 & 0.23466 & - & 2263 \\
France & 0.29502 & 0.36255 & 0.33475 & 0.44985 & 0.35846 & 0.39850 & $\mathbf{0 . 5 8 3 5 4}$ & 0.56575 & - \\
\hline
\end{tabular}

grouping corresponds to the UPGMA dendrogram of all samples based on Jaccard's similarity coefficient, showing the relationships between all 114 individuals and the PCoA-plot (Fig. 2).

A dendrogram based on Nei's genetic distance between populations (results not shown) reveals a similar clustering, except for an exchange of position of groups I and IV. The Spanish population of $C$. s. xanthostoma (Dumont, 1972), often considered a valid species, is a distinct cluster. Surprisingly, the French and Azeiri populations (group I) show a close relationship to each other and the Finnish and Slovenian populations are the most divergent group of all.

An estimation of gene flow between populations $\left(N_{m}\right)$ (Table 4) was obtained from the AMOVA-derived pairwise $\varphi s t$ distances. Populations with $N_{m}>1$ are considered to be genetically homogeneous in the absence of counteracting forces. These results reveal the presence of a high gene exchange rate $\left(N_{m}=3.0073\right)$ between Russian and Kazakh populations. The only other exchange with a value above one is between the Turkish and Russian populations $\left(N_{m}=1.1021\right)$. The lowest gene flow $\left(N_{m}=\right.$ 0.1784 ) is between the Slovenian and French populations.

Together, these results establish a lack of differentiation between Russian and Kazakh populations, and their close relationship with Turkish populations. On the other hand, the Slovenian and the Finnish populations are closely related, but well differentiated from French and Spanish populations.

To further explore the data, a three-level hierarchical analysis in which variation was partitioned at different levels (between groups, between populations within groups, and within populations) was applied. First, we placed all populations into a number of groups on the basis of their wing spot phenotype (model 2) or their geographical origin (model 3). Grouping individuals by geographic locality can be problematic because boundaries may be arbitrary and population allele frequencies may be biased by migration and inter-population hybridization (Allendorf \& Luikart, 2007). When grouping the populations on the basis of the general appearance of their wing spots a statistically non-significant differentiation $(1.13 \%)$ between groups was found (Table 5, model 2). This indicates that among the populations studied no genetically defined taxa based on wing spot variation could be identified.

In contrast, grouping on the basis of geographical differentiation revealed a striking difference between groups and between populations within groups. Although no prominent differences were present between the European and the Asian groups (Group 1: Asia; Group 2: Europe; model 3, Table 5, model 3), it seems that a deep genetic differentiation $(16.95 \%)$ is present between populations from Asia, Western Europe (France and Spain), and Central Europe (Finland and Slovenia) (Table 5, model 4). The fifth model was based on the grouping seen in the PCoA plots and UPGMA-trees (Figs 2, 4). AMOVA showed that this population grouping correlates with the maximum amount of differentiation between groups (23.26).

TABLE 4. Matrix of estimated gene flow $\left(N_{m}\right)$; maximum and minimum values are in bold type.

\begin{tabular}{|c|c|c|c|c|c|c|c|c|c|}
\hline Populations & Azerbaijan & France & Finland & Iran & Kazakhstan & Russia & Slovenia & Spain & Turkey \\
\hline Azerbaijan & - & & & & & & & & \\
\hline France & 0.5947 & - & & & & & & & \\
\hline Finland & 0.2179 & 0.1919 & - & & & & & & \\
\hline Iran & 0.3329 & 0.4396 & 0.4049 & - & & & & & \\
\hline Kazakhstan & 0.2614 & 0.3058 & 0.2591 & 0.3657 & - & & & & \\
\hline Russia & 0.3379 & 0.4475 & 0.3935 & 0.7083 & 3.0073 & - & & & \\
\hline Slovenia & 0.1853 & 0.1784 & 0.8154 & 0.6339 & 0.2809 & 0.4346 & - & & \\
\hline Spain & 0.3351 & 0.3774 & 0.2035 & 0.3668 & 0.2067 & 0.4092 & 0.2149 & - & \\
\hline Turkey & 0.7069 & 0.4969 & 0.4296 & 0.6087 & 0.8814 & 1.1021 & 0.3976 & 0.5252 & - \\
\hline
\end{tabular}


TABLE 5. Results of analysis of molecular variance (AMOVA) based on haplotype scores of 333 AFLP loci among 9 populations of $C$. splendens.

\begin{tabular}{|c|c|c|c|c|c|}
\hline \multicolumn{6}{|c|}{ AMOVA model analyzed } \\
\hline & Model 1 & Model 2 & Model 3 & Model 4 & Model 5 \\
\hline & $\begin{array}{l}\text { G: Az, Ir, Tu, Ru, } \\
\text { Ka, Fr, Sp, Sl, Fi }\end{array}$ & $\begin{array}{c}\text { G1: Az, Ir, Tu, Sp } \\
\text { G2: S1, Fi, Fr, Ru, } \\
\text { Ka }\end{array}$ & $\begin{array}{l}\text { G1: Az, Ir, Tu, Ru, Ka } \\
\text { G2: Sp, Fr, Fi, S1 }\end{array}$ & $\begin{array}{c}\text { G1: Az, Tu, Ir, Ru, } \\
\text { Ka } \\
\text { G2: Fi, S1 } \\
\text { G3: Fr, Sp }\end{array}$ & $\begin{array}{c}\text { G1: Tu, Ir, Ru, Ka } \\
\text { G2: Az, Fr } \\
\text { G3: Fi, Sl } \\
\text { G4: Sp }\end{array}$ \\
\hline \multicolumn{6}{|c|}{ AMOVA results as $\%$ genetic variance } \\
\hline Between groups & - & 1.13 & 0.7 & $16.95 * *$ & $23.26^{* *}$ \\
\hline $\begin{array}{l}\text { Between populations } \\
\text { wthin groups }\end{array}$ & $39.20 * *$ & $38.38 * *$ & $38.69 * *$ & $25.97 * *$ & $19.60^{* *}$ \\
\hline Within populations & $60.80 * *$ & $60.49 * *$ & $60.61 * *$ & $57.08 * *$ & $57.14 * *$ \\
\hline
\end{tabular}

\section{DISCUSSION}

In recent years, molecular genetic studies have lead to novel insights into the spatial genetic structure of aquatic insects (Kelly et al., 2002; Hughes et al., 2003; Wilcock et al., 2003).

In many cases, molecular results have supported classical morphological work, but there are cases where unexpected novelty emerges (Parkes et al., 2009).

Parkes et al. (2009) resolved the longstanding debate about the sub-specific level of Sympetrum striolatum and $S$. nigrescens using AFLP. They found no evidence to support a specific difference between them, but show that there is a clear pattern of isolation and population groupings caused by a salt water barrier to gene flow.

Here, we explore the genetic structure of nine geographically separated populations of $C$. splendens, a complex damselfly that has been the subject of much debate in past decades. We investigated whether wing spot differences (size and shape) between these populations (or subspecies), correspond to genetic differentiation, suspecting that traditional wing spot taxonomy might simplify reality too much, given that almost any wing spot can result from the hybridization of several possible parental forms.

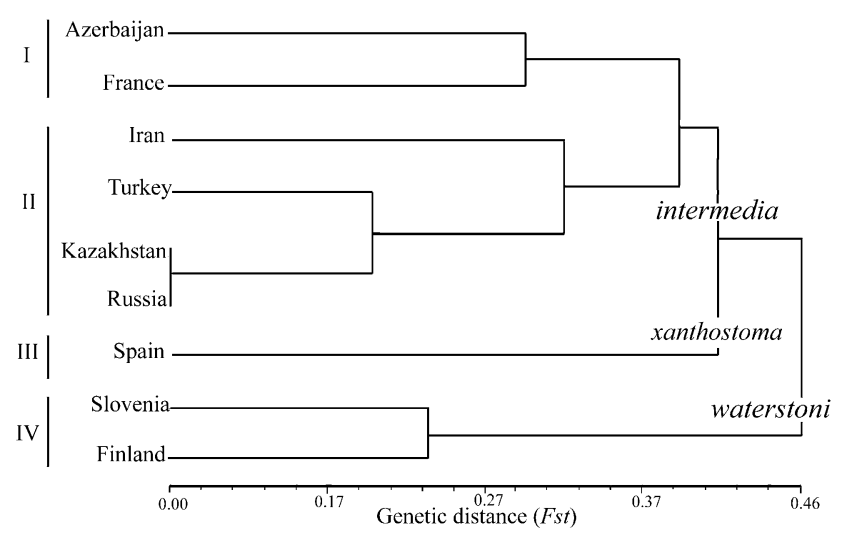

Fig. 4. UPGMA dendrogram based on the AMOVA-derived $F_{S T}$ distance between populations of nine $C$. splendens populations based on AFLP data.
Populations within species can currently be identified using multilocus allele frequencies and statistical approaches for clustering individuals or populations (Allendorf \& Luikart, 2007). For assessing the genetic relationships among our $C$. splendens, AFLP was used because this method allows the analysis of multiple loci in genomes with an unknown sequence composition.

Pairwise population comparisons of Nei's genetic distance and $F_{S T}$ are interpreted as standardized interpopulation distances between populations. Our AMOVA result for the fifth model $\left(\varphi_{\mathrm{st}}=0.4286\right)$ explained $57 \%$ of the variation within populations and $20 \%$ of the variation among populations within groups, possibly due to little gene flow between collection sites or insufficient time for populations to reach equilibrium. Although $F_{S T}$ is influenced by the number of populations analyzed and by the way in which individual populations are defined and sampled (Jorde, 1980; Urbanek et al., 1996) we identified striking differences between our samples.

The genetic differentiation of our samples is larger than that found by Svensson et al., (2004) in Sweden (overall $\left.F_{S T}=0.054\right)$. They report much more genetic variation within populations $(94.57 \%)$, which is explained by the geographical nearness of their populations. It is also larger than that reported by Chaput-Bardy et al. (2008) for populations about $500 \mathrm{~km}$ apart, whereas our study encompassed the entire width of the geographic range of the species. Compared with other groups of insects, our results are similar to $\varphi_{\text {st }}$ values for winter pine moth in the Mediterranean region (Salvato et al., 2002), which ranges from 0.243 to 0.480 , but higher than in tephritid flies (Urophora cardui) (0.096 to 0.161) (Eber \& Brandl, 1997) and caddisflies (Plectrocnemia conspersa) in Europe (0.1260) (Wilcock et al., 2003).

Based on Wright's formula $\left(F_{S T}=1 /\left(1+4 N_{m}\right)\right.$, a combination of parameters reveals the relative strength of gene flow and genetic drift. Genetic drift generates substantial local differentiation if $N_{m}<1$ but not if $N_{m}>1$ (Slatkin, 1987). Our analysis found little gene flow between most populations except those of the Asian group. A better understanding of the relatedness between Russian and Kazakh populations and between Turkish 
and Iranian populations, and the climatic history of Central Asia, may provide relevant clues.

Currently this area is largely arid or semi-arid, with the Caspian Lake level at -25 to $-28 \mathrm{~m}$, but a more humid climate in the past may have prompted genetic mixing. In fact, the humidity of the Pontocaspian area has continuously fluctuated over most of the Pleistocene, with the Caspian, Black, and Aral seas repeatedly united into a single lake with surface level at c. $+45 \mathrm{~m}$. One such episode occurred shortly before the last glaciation (40-70 kyr ago) (Kosarev \& Yablonskaya, 1994). At that time, all major regional rivers, starting with the Danube in the west, the Volga, Ural, and the Amu and Syr Darya in the east, emptied in a single giant Ponto-caspian water body, and dispersal of aquatic insects across this enormous basin was facilitated. Contacts with the Baltic in Eastern Europe and the $\mathrm{Ob}$ and Irtysh rivers in Western Siberia, via the upper reaches of Uralian rivers, must have been relatively easy. They are still reflected in reduced genetic differentiation between the regional Calopteryx subspp., which is consistent with the definition of ancillaintermedia, even if in the Turkish and, especially Iranian populations we suspect a presence of the orientalis genome. The Finnish and Slovenian populations could be part of another wave of dispersal that used the Danube or Dniepr as a pathway, as their genome is enriched with alleles that could be derived from waterstoni.

The $C$. splendens in France is genetically distinct from Spanish C. xanthostoma, although xanthostoma also occurs in the south of France. Such a differentiation is consistent with previous morphological and phylogenetic studies by Dumont (1972), Weekers et al. (2001) and Dumont et al. (2005a), who conclude that the west Mediterranean refugium allowed xanthostoma to survive the glaciations. Hybridization between the taxa splendens and xantostoma is reported: Papazian (1995) claims there is little contact between them in the south of France, but Pavesi (pers. com.), conversely, finds that in Northern Italy, xanthostoma is being introgressed by splendens at a rate measurable in terms of a human lifetime.

Curiously, there is a remote relationship between the "ancilla" cluster of populations and C. xanthostoma, which is closer than that with the "waterstoni" cluster. This might revive an old hypothesis by Bodenheimer (1935) that a corridor suitable for Calopteryx dispersal once existed across a more humid North Africa. To test this idea, an analysis of "intermedia" populations from Northern Syria-Hatay and Northern Iraq, as well as from the Jordan-Litani valleys (Calopterxyx syriaca) (Dumont, 1975a) will be required.

The relationship between the French and Azeiri (Kura) populations, with regard to their geographical position, is puzzling. Both populations are situated near the foot of mountain chains (the Pyrenees and Caucasus). Such mountain chains no doubt impede the rapid spread of the first invaders during inglacials (Hewitt, 2001). Afterwards, in contrast, they may have functioned as microrefugia that conserved some old genomes, perhaps dating back to the early Würm III deglaciation. These are currently, but slowly, invaded by "new" genes. Indeed, our results illustrate that while some clear groupings can be distinguished within the nine populations studied, virtually all populations have some gene-flow with other groups. This suggests a complex history of expansion and contraction of populations, with wave upon wave rolling over previously inhospitable territory. Calopteryx is considered a "slow" disperser, with many individuals spending their adult life within a few hundred meters of their place of emergence. Yet, a few individuals may travel several kilometers and cross the divide between adjacent streams (Stettmer, 1996; Ward \& Mill, 2005). In around one millennium, consecutive generations of such individuals may carry their particular genome across the entire range of the species. The low sea levels around $18,000 \mathrm{BP}$ and in the few millenia thereafter, making it much easier to cross from Anatolia to Greece, into Italy, and finally to southern France, make this a plausible scenario.

With this in mind, it becomes understandable why Russian, Kazakh, and the Turkish populations show high gene flow and low genetic differentiation while their wing spots differ. Conversely, French and Slovenian populations have a high genetic differentiation but a similar wing spot. These observations imply that genetically defined groups of $C$. splendens may, but do not necessarily, correspond to traditionally recognized taxa based on wing spot characteristics. Local adaptation (Guppy, 1986; Brakefield \& Reitsma, 1991), character displacement due to coexistence with related species (Waage, 1975, 1979; Tynkkyen et al., 2004), parasites hosted (Siva-Joty, 2000; Koskimaki, 2004) and environmental factors (Kolyer, 1966, Torres et al., 1992; Hooper et al., 1999) may affect size and density of wing pigmentation. Therefore, wing spot similarity cannot capture the full genetic grouping of populations. Finally, nothing has been said so far about $C$. splendens splendens, the type subspecies, found in Western Europe and the British Isles. From the present analysis it follows, however, that no single genome adequately represents this taxon. It probably is a complex hybrid, containing elements of the gene pools of waterstoni and ancilla.

\section{General conclusion}

Morphological differentiation of $C$. splendens is restricted to wing spot features. This character has been used extensively by morpho-taxonomists, but is not sufficiently powerful for subspecific delineation; in contrast, the genetic structure of populations revealed in this study, although not covering the full genetic variation now suspected to be present, show that genetic differences between and within populations are a more informative criterion in subspecific or specific classification.

Based on the results of this study it is suggested there are four atavistic (probably pre-Pleistocene) gene pools (more may exist but currently there is no evidence for this): waterstoni, ancilla (= intermedia), orientalis, and xanthostoma. Individuals of all four gene pools may hybridize when they meet, as they expand their range along rivers as climate allows. From late-Pleistocene they 
first dispersed from refugia in western Asia (ancilla, orientalis, and waterstoni) or North Africa-Iberia (xanthostoma), partly mixed in the Ponto-Caspian basin and then invaded Europe and Siberia, in consecutive waves. Contact between the populations that resulted from these invasions resulted in a variety of phenotypes that can only partly be characterized by size and shape of the wing spot in males, but their genetic basis is revealed by AFLP analysis.

ACKNOWLEDGEMENTS. Special thanks to M. Sadeghi, R. Sadeghi, A.R. Rahbarpoor, Y. Tahamtani, and J. Alizadeh (Hamedan University) for their help in obtaining samples from Iran. H.J. Dumont thanks his numerous colleagues who sent specimens from the four corners of Eurasia. We thank A. Vierstraete for assistance with the capillary electrophoresis and technical problems.

\section{REFERENCES}

Albert V., Jonsson B. \& Bernatchez L. 2006: Natural hybrids in Atlantic eels (Anguilla anguilla, A. rostrata): evidence for successful reproduction and fluctuating abundance in space and time. Mol. Ecol. 15: 1903-1191.

Allendorf F.W. \& LUIKART G. 2007: Conservation and the Genetics of Populations. Blackwell Scientific, Malden, MA, $664 \mathrm{pp}$.

Askew R.R. 2004: The Dragonflies of Europe. Midas Printing, China, $308 \mathrm{pp}$

Bensch S. \& Åkesson M. 2005: Ten years of AFLP in ecology and evolution: why so few animals? Mol. Ecol. 14: 2899-2914.

Bodenheimer F.S. 1935: Animal Life in Palestine. Mayer, Jerusalem, $507 \mathrm{pp}$.

Brakefiel P.M. \& Reitsma N. 1991: Phenotypic plasticity, seasonal climate and the population biology of Bycyclus butterflies (Satyridae) in Malawi. Ecol. Entomol. 16: 291-303.

Chaput-Bardy A., Lemaire C., Picard D. \& Secondi J. 2008: In-stream and overland dispersal across a river network influences gene flow in a freshwater insect, Calopteryx splendens. Mol. Ecol. 17: 3496-3505.

Clark A.G. \& Lanigan C.M. 1993: Prospects for estimating nucleotide divergence with RAPDs. Mol. Biol. Evol. 10: 1096-1111.

CORBET P.S. 2004: Dragonflies, Behaviour and Ecology of Odonata. Rev. ed. Harley Books, Essex, 829 pp.

CORdoba-Aguilar A. 2002: Wing pigmentation in territorial male damselflies, Calopteryx haemorrhoidalis; a possible relation to sexual selection. Anim. Behav. 63: 759-766.

Dumont H.J. 1972: The taxonomic status of Calopteryx xanthostoma (Charpentier, 1825) (Zygoptera: Calopterigidae). Odonatologica 1: 21-29.

Dumont H.J. 1975a: Endemic dragonflies of late Pleistocene age of the Hula lake area (North Israel), with notes on the Calopterygidae of the rivers Jordan (Israel, Jordan) and Litani (the Lebanon), and description of Urothemis edwardsi hulae subspec. nov. (Libellulidae). Odontologica 4: 1-9.

Dumont H.J. 1975b: A note on some dragonflies from Afghanistan. Odonatologica 4: 243-248.

Dumont H.J., Demirsoy A. \& Verschuren D. 1987: Breaking the Calopteryx-bottleneck: taxonomy and range of Calopteryx splendens waterstoni Schneider, 1984 and C. splendens tschaldirica Bartenef, 1909 (Zygoptera: Calopterygidae). Odonatologica 16: 239-247.

Dumont H.J., Haritonov A.Y. \& Borisov S.N. 1992: Larval morphology and range of three West Asiatic species of the genus Onychogomphus Selys, 1854 (Insecta: Odonata). Hydrobiologia 245: 169-177.

Dumont H.J., Heidari H. \& Atamuradov K.I. 1997: Hybridisation in Calopteryx orientalis (Selys) East of the shores of the south Caspian lake (Zygoptera: Calopterygidae). Odonatologica 26: 205-213.

Dumont H.J., Vanfleteren J.R., De Jonckheere J.F. \& WeekERS P.H.H. 2005: Phylogenetic relationships, divergence time estimation, and global biogeographic patterns of calopterygoid damselflies (Odonata, Zygoptera) inferred from ribosomal DNA sequences. Syst. Biol. 54: 347-362.

EbER S. \& BRANDL R. 1997: Genetic differentioation of the tephritid fly Urophora cardui in Europe as evidence for its biogeographical history. Mol. Ecol. 6: 651-660.

Evanno G., Regnaut S. \& Goudet J. 2005: Detecting the number of clusters of individuals using the software STRUCTURE : a simulation study. Mol. Ecol. 14: 2611-2620.

Excoffier L., Laval G. \& Schneider S. 2005: Arlequin ver. 3.0: An integrated software package for population genetics data analysis. Evol. Bioinform. 1: 47-50.

Falush D., Stephens M. \& Pritchard J.K. 2003: Inference of population structure using multilocus genotype data: linked loci and correlated allele frequencies. Genetics 164: 1567-1587.

Falush D., Stephens M. \& Pritchard J.K. 2007: Inference of population structure using multilocus genotype data: dominant markers and null alleles. Mol. Ecol. Notes 7: 574-578.

GRETHER G.F. 1996: Sexual selection and survival selection on wing coloration and body size in the rubyspot damselfly Hetaerina americana. Evolution 50: 1939-1948.

Guppy C.S. 1986: The adaptive significance of alpine melanism in the butterfly Parnassius phoebus F. (Lepidoptera: Papilionidae). Oecologia 70: 205-213.

HewitT G.M. 2001: Speciation, hybrid zones and phylogeography - or seeing genes in space and time. Mol. Ecol. 10: 537-549.

Hooper R.E., Tsubaki Y. \& Siva-Jothy M.T. 1999: Expression of a costly secondary sexual trait is correlated with age and condition in a damselfly with two male morphs. Physiol. Entomol. 24: 364-369.

Hopeman M. \& Abramson Z.R. 2005: Sexual dimorphism in the dark-winged damselfly Calopteryx Maculata. Online: http://www.umich.edu/ umforum/Issue2/Issue2-p28.pdf.

Hughes J.M., Mather P.B., Hillyer M.J., Cleary C. \& Peckarsky B. 2003: Genetic structure in a montane mayfly Baetis bicaudatus (Ephemeroptera: Baetidae), from the Rocky Mountains, Colorado. Freshwat. Biol. 48: 2149-2162.

Innan H., Terauchi R., Kahl G. \& Tajima F. 1999: A method for estimating nucleotide diversity from AFLP data. Genetics 151: $1157-1164$.

JACCARD P. 1908: Nouvelles recherches sur la distribution florale. Bull. Soc. Vaud. Sci. Nat. 44: 223-270.

JORDE L. 1980: The genetic structure of human populations: A review. In Mielke J. \& Crawford M. (eds): Current Developments in Anthropological Genetics. Plenum, New York, pp. 135-208.

Kelly L.C., Bilton D.T. \& Rundle S.D. 2002: Genetic population structure and dispersal in Atlantic Island caddisflies. Freshwat. Biol. 47: 1642-1650.

KoLYeR J.M. 1966: The effect of certain environmental factors and chemicals on the markings of Pieris rapae (Pieridae). $J$. Lepidopt. Soc. 20: 13-27.

Kosarev A.N. \& Yablonskaya E.A. 1994: The Caspian Sea. SPB Academic Publishing, The Hague, 260 pp.

Koskimaki J., Markus K.I., Rantala J., Taskinen J., TynkKynen K. \& Suhonen K. 2004: Immunocompetence and resource 
holding potential in the damselfly, Calopteryx virgo L. Behav. Ecol. 15: 169-173.

Lindeboom M. 1998: Post-copulatory behaviour in Calopteryx females (Insecta, Odonata, Calopterygidae). Int. J. Odonatol. 1: $175-184$

Lowe A.J., Jourde B., Breyne P., Colpaert N., Navarro C., WILSON J. \& CAVERS S. 2003: Fine-scale genetic structure and gene flow within Costa Rican populations of mahogany (Swietenia macrophylla). Heredity 90: 268-275.

LyNCH M. \& Milligan B.G. 1994: Analysis of population genetic structure with RAPD markers. Mol. Ecol. 3: 91-99.

Mantel N. 1967: The detection of disease clustering and a generalized regression approach. Cancer Res. 27: 209-220.

Mueller U.G. \& WolfenBarger L.L. 1999: AFLP genotyping and fingerprinting. Trends Ecol. Evol. 14: 389-394.

NeI M. 1973: Analysis of gene diversity in subdivided populations. Proc. Nat. Acad. Sci. USA 70: 3321-3323.

Papazian M. 1995: Etude systématique et biogéographique de Calopteryx splendens (Harris, 1782) en Provence (Odonata, Zygoptera). Bull. Soc. Entomol. Fr. 100: 361-376

Parkes K.A., Amos W., Moore N.W., Hoffman J.I. \& Moore J. 2009: Population stracture and speciation in the dragonfly Sympetrum strialatum/nigrescens (Odonata: Libellulidae): An analysis using AFLP markers. Eur. J. Entomol. 106: 179-184.

Pritchard J.K. \& Rosenberg N.A. 1999: Use of unlinked genetic markers to detect population stratification in association studies. Am. J. Hum. Genet. 65: 220-228.

Pritchard J., Stephens M. \& Donnelly P. 2000: Inference of population structure using multilocus genotype data. Genetics 155: 945-959.

RosenbERG N.A. 2004: DISTRUCT, a program for the graphical display of population structure. Mol. Ecol. Notes 4: 137-138.

Rosenberg N.A., Pritchard J.K., Weber J.L., Cann H.M., Kidd K.K., Zhivotovsky L.A. \& Feldman M.W. 2002: Genetic structure of human populations. Science 298: 2381-2385.

Rohlf F.J. 2004: NTSYSpc Numerical Taxonomy and Multivariate Analysis System. Version 2.11 User Guide. Exeter Software, Setauket, NewYork.

Salvato A., Battisti A., Concato S., Masuitti L., Patarnello T. \& ZANE L. 2002: Genetic differentiation in the winter pine processionary moth (Thaumetopoea pityocampa-wilkinsoni complex), inferred by AFLP and mitochondrial DNA markers. Mol. Ecol. 11: 2435-2444.

SChNeider S., Kuffer J.M., Roessli D. \& Exoffier L. 1996 Arlequin: A Software Package for Population Genetics. Version 3.1.1. Genetics, Biometry Lab, Department of Anthropology, University of Geneva.

Schneider S., Roessli D. \& Exoffier L. 2000: Arlequin: A Software Package for Population Genetics. Biometry Lab, Department of Anthropology, University of Geneva.

Siva-JotтнY M. 2000: A mechanistic link between parasite resistance and expression of sexually selected trait in a damselfly. Proc. R. Soc. Lond. 267: 2523-2527.

SLATKIN M. 1987: Gene flow and geographic structure of natural populations. Science 236: 787-292.

SlatKin M. 1989: Detecting small amounts of gene flow from phylogenies of alleles. Genetics 121: 609-612.

SLATKIN M. 1991: Inbreeding coefficients and coalescence times. Genet. Res. 58: 167-175.

SOKAL R.R. \& Michener C.D. 1958: A statistical method for evaluating systematic relationships. Univ. Kansas Sci. Bull. 38: $1409-38$.
SoKal R.R. \& Rohlf F.J. 1995: Biometry: The Principles and Practice of Statistics in Biological Research. 3rd. ed. W.H. Freeman, San Francisco.

SOKAL R.R. \& WARTENBERG D.E. 1983: A test of spatial autocorrelation analysis using an isolation-by-distance model. Genetics: 105, 219-237.

StetTMER C. 1996: Colonisation and dispersal patterns of banded (Calopteryx splendens) and beautiful demoiselles (C. virgo) (Odonata: Calopterygidae) in south-east German streams. Eur. J. Entomol. 93: 579-593.

Svensson E.I., Kristoffersen L., Oskarsson K. \& Bensch S. 2004: Molecular population divergence and sexual selection on morphology in the banded demoiselle (Calopteryx splendens). Heredity 93: 423-433.

Torres C., Ribas G., Xamena N., Creus A. \& Marcos R. 1992: Genotoxicity of four herbicides in the Drosophila wing spot. Mutat. Res. 280: 291-295.

Tynkkynen K., Rantala M.J. \& Suhonen J. 2004: Interspecific aggression and character displacement in the damselfly Calopteryx splendens. J. Evol. Biol. 17: 259-267.

Urbanek M., Goldman D. \& Long J.C. 1996: The apportionment of dinucleotide repeat diversity in Native Americans and Europeans: A new approach to measuring gene identity reveals asymmetric patterns of divergence. Mol. Biol. Evol. 13: $943-953$

VeKemans X. 2002: AFLP-SURV version 1.0. Distributed by the author. Laboratoire de Genetique et Ecologie Vegetale, Universitè Libre de Bruxelles, Belgium, (http://www.ulb.ac. be/sciences/lagev/aflp-surv.html).

Vos P., Hogers R., Bleeker M., Reijans M., Van de Lee T., Hornes M., Frifiters A., Pot J., Peleman J., Kuiper M. \& XabeaU M. 1995: AFLP: A new technique for DNA fingerprinting. Nucl. Acids Res. 23: 4407-4414.

WAAGE J.K. 1975: Reproductive isolation and the potential for character displacement in the damselflies, Calopteryx maculate and C. aequabilis (Odonata: Calopterygidae). Syst. Zool. 24: $24-36$.

WAAGE J.K. 1979: Reproductive character displacement in Calopteryx (Odonata: Calopterygidae). Evolution 33: 104-116.

WARD L. \& Mill P.J. 2005: Habitat factors influencing the presence of adult Calopteryx splendens (Odonata: Zygoptera). Eur. J. Entomol. 102: 47-51.

Weekers P.H.H., De Jonckheere F.J. \& Dumont H.J. 2001: Phylogenetic relationships inferred from ribosomal ITS sequences and biogeographic patterns in representative of the genus Calopteryx (Insecta: Odonata) of the West Mediterranean and adjacent west European zone. Mol. Phylogen. Evol. 20: 89-99.

Wilcock H.R., Nichols R.A. \& Hildrew A.G. 2003: Genetic population structure and neighborhood population size estimates of the caddisfly Plectrocnemia conspersa. Freshwat. Biol. 48: 1813-1824.

Wright S. 1951: The genetic structure of populations. Ann. Eugen. 15: 323-354.

ZhivotovsKY L.A. 1999: Estimating population structure in diploids with multilocus dominant DNA markers. Mol. Ecol. 8: 907-913.

Received September 7, 2009; revised and accepted December 21, 2009 